\title{
Influence of cultivation technology on the health of spring wheat
}

\author{
Wpływ technologii uprawy na zdrowotność pszenicy jarej
}

\author{
Leszek Majchrzak, Zuzanna Sawinska, Grzegorz Skrzypczak, Tomasz Piechota
}

\section{Summary}

The studies were conducted at the Research and Education Center Gorzyń, the branch Brody that belongs to the Poznań University of Life Sciences in the years 2011-2013. The aim of the study was to determine the severity of infection by pathogenic fungi on spring wheat depending on spring wheat cultivation technology: cover crop cultivation (without cover crop, sowing after skimming and direct drilling) and different tillage system (conventional, reduced tillage and direct drilling). The results revealed that the direct sowing caused higher infection of spring wheat by the stem base and root diseases. Higher infection of Fusarium spp. and Gaeumannomyces graminis was observed on the treatments without white mustard biomass each year of the study. Percentage of damage plants and the index of infection caused by pathogens of stem base diseases depended on the experimental factors of the studies. Higher infection was observed on the treatments without cover crop cultivation where spring wheat was cultivated in no-tillage technology.

Key words: spring wheat; diseases; cover crop; tillage system

\section{Streszczenie}

Badania przeprowadzono w latach 2011-2013 w Zakładzie Doświadczalno-Dydaktycznym Gorzyń, filii Brody należącym do Uniwersytetu Przyrodniczego w Poznaniu. Ich celem była ocena stopnia porażenia pszenicy jarej przez grzyby chorobotwórcze w zależności od technologii uprawy pszenicy jarej: sposobu uprawy międzyplonu gorczycy białej (bez międzyplonu, wysiewanego po podorywce i siewie bezpośrednim) oraz sposobu uprawy pszenicy (tradycyjny, uproszczony i siew bezpośredni). Wykazano, że wykonanie siewu bezpośredniego przyczyniło się do większego porażenia pszenicy jarej przez choroby podstawy źdźbła i korzeni. W obiektach, w których nie pozostawiano biomasy z gorczycy białej, w każdym roku badań obserwowano wyższe porażenie zarówno fuzaryjną zgorzelą podstawy źdźbła, jak i zgorzelą podstawy źdźbła. Procent uszkodzeń roślin, jak i wartość indeksu porażenia przez grzyby powodujące zgorzel podstawy źdźbła uzależnione były od badanych czynników doświadczalnych. Wyższe porażenie obserwowano w obiektach bez uprawy międzyplonu, w których pszenicę jarą uprawiano w technologii bezorkowej.

Słowa kluczowe: pszenica jara; choroby; międzyplon ścierniskowy; sposób uprawy

\author{
Uniwersytet Przyrodniczy w Poznaniu \\ Katedra Agronomii \\ Dojazd 11, 60-632 Poznań \\ leszmaj@up.poznan.pl
}




\section{Wstęp / Introduction}

Pszenica jara jest rośliną o dość wysokich wymaganiach przedplonowych. Najlepsze plony uzyskuje się uprawiając ją po roślinach okopowych lub strączkowych. Przy uproszczeniu zmianowania i uprawie po roślinach zbożowych reaguje 15-20\% spadkiem plonu. Jedną z istotnych przyczyn obniżenia poziomu plonowania pszenicy jarej uprawianej w uproszczonym zmianowaniu zbożowym jest jej porażenie przez choroby powodowane przez grzyby. Spośród chorób powodowanych przez grzyby patogeniczne związane ze środowiskiem glebowym za najgroźniejsze uważa się choroby podsuszkowe określane często jako „choroby płodozmianowe” (Huber i McCayBius 1993; Kurowski 2002), które w znacznym stopniu występują w zbożach ozimych, zwłaszcza pszenicy, a w mniejszym stopniu w zbożach jarych. Systemy bezorkowe powodują zwiększenie zawartości substancji organicznej w powierzchniowej warstwie i poprawiają aktywność biologiczną gleby, co może ograniczać populację patogenów (Krupinsky i wsp. 2007). Wyniki badań dotyczące wpływu systemów uprawy roli na występowanie chorób grzybowych w zbożach są ciągle niejednoznaczne (Weber i wsp. 2001). Zdaniem Czabana i wsp. (2011) bardziej intensywne technologie uprawy pszenicy ozimej z większą ilością nawozów i środków ochrony roślin oraz przyorywaniem słomy przyczyniają się do silniejszego zasiedlania ziarniaków przez Fusarium ssp., a także większej różnorodności tych grzybów. Natomiast badania przeprowadzone przez Pląskowską i wsp. (2002) wskazują, że nawet przy znacznym ograniczeniu zabiegów uprawowych pszenica nie była w większym stopniu atakowana przez patogeniczne grzyby zasiedlające glebę, niż uprawiana tradycyjnie. W przypadku stosowania uproszczonych systemów uprawy roli wzrasta rola międzyplonów jako czynnika poprawiającego bilans substancji organicznej w glebie (Wojciechowski 2005), ograniczającego wymywanie azotanów do wód gruntowych, zwiększającego aktywność biologiczną i potencjał fitosanitarny gleby oraz chroniącego glebę przed erozją (Duer 1996; Richards i wsp. 1996).

Celem badań była ocena stopnia porażenia pszenicy jarej w zależności od technologii jej uprawy.

\section{Materiały i metody / Materials and methods}

W latach 2011-2013 w Katedrze Agronomii Uniwersytetu Przyrodniczego w Poznaniu, Zakładzie Dydaktyczno-Doświadczalnym Gorzyń, filii Brody, przeprowadzono doświadczenia polowe mające na celu ocenę wpływu technologii uprawy pszenicy jarej na jej zdrowotność w kontekście nasilenia występowania chorób. Pszenicę corocznie wysiewano na tym samym polu w różnych technologiach (różny sposób uprawy międzyplonu lub jego brak oraz zróżnicowany sposób przygotowania gleby pod wysiew pszenicy jarej). Ocenę porażenia roślin przeprowadzono corocznie w fazie dojrzałości wodnej do mlecznej pszenicy jarej (BBCH 71-75) na 100 roślinach losowo pobranych z kombinacji, określając odsetek źdźbeł z objawami porażenia. Nasilenie chorób podsuszkowych wyrażono dodatkowo indeksem porażenia w skali 0-1, wyliczonym według metodyki EPPO 1/28(3).

Uzyskane wyniki poddano ocenie statystycznej z zastosowaniem analizy wariancji, po uprzednim ich przekształceniu według wzoru $\mathrm{y}=\arcsin \sqrt{\mathrm{x}}$. Istotność zróżnicowania wyników oceniono testem Fishera-Snedecora na poziomie istotności $\mathrm{p}=0,05$, natomiast badanie istotności różnic pomiędzy średnimi szacowano testem Tuckeya.

\section{Wyniki i dyskusja / Results and discussion}

Porażenie pszenicy jarej przez grzyby rodzaju Oculimacula yallundae było istotnie zróżnicowane w poszczególnych latach badań. Najniższy procent źdźbeł z objawami łamliwości podstawy źdźbła notowano w roku 2011 (1,59\%), a istotnie najwyższy w roku 2013 (3,55\%). Przy uprawie pszenicy po przedplonie gorczycy białej wysiewanej po podorywce porażenie roślin pszenicy przez $O$. yallundae kształtowało się na poziomie $1,74 \%$, a w siewie bezpośrednim 2,74\% (tab. 1). Stwierdzono zależność pomiędzy latami prowadzenia badań a sposobem uprawy gleby pod wysiew międzyplonu. Niższe porażenie pszenicy jarej obserwowano w roku 2011 w obiektach, w których pszenicę wysiewano po gorczycy uprawianej w technologii siewu bezpośredniego - 1,22\%, natomiast w roku 2013 porażenie pszenicy w tych obiektach było najwyższe i wynosiło $5 \%$.

Sposób uprawy gleby zarówno pod wysiew międzyplonu, jak i pod wysiew pszenicy nie miał istotnego wpływu na stopień porażenia roślin pszenicy przez choroby podstawy źdźbła (tab. 2, 4). Istotność różnic porażenia pszenicy przez grzyby powodujące fuzaryjną zgorzel podstawy źdźbła wykazano w latach prowadzenia badań (tab. 3). Było ono istotnie najwyższe w roku 2011 i wynosiło $26,6 \%$. Na stopień porażenia roślin nie miał istotnego wpływu sposób uprawy gleby pod wysiew pszenicy. Średnio w latach badań najniższym porażeniem charakteryzowały się rośliny pszenicy w obiektach z uproszczoną uprawą gleby pod wysiew pszenicy, gdzie stosowano agregat uprawowy. Indeks porażenia roślin pszenicy jarej w doświadczeniu polowym w odniesieniu do fuzaryjnej zgorzeli podstawy źdźbła był istotnie modyfikowany przez lata prowadzenia badań, co związane było bezpośrednio $\mathrm{z}$ przebiegiem warunków meteorologicznych (tab. 3). Najwyższym indeksem porażenia charakteryzowały się rośliny pszenicy we wszystkich obiektach uprawowych $\mathrm{w}$ roku 2011, a istotność różnic potwierdzono zarówno w odniesieniu do roku 2012, jak i 2013. Nie odnotowano istotnych statystycznie różnic w indeksie porażenia podstawy źdźbła i korzeni pszenicy jarej przez Gaeumannomyces graminis w zależności od sposobu jej uprawy (tab. 4). Najwyższe wartości indeksu wykazano w obiektach $\mathrm{z}$ siewem bezpośrednim $(4,5)$, a najniższe $\mathrm{w}$ obiektach $\mathrm{z}$ tradycyjną uprawą roli pod wysiew pszenicy $(2,9)$. Wystąpiła również zależność pomiędzy sposobem uprawy międzyplonu (gorczycy białej) a sposobem uprawy gleby pod wysiew pszenicy. Najwyższym indeksem nasilenia choroby podstawy źdźbła 
Tabela 1. Procent oraz indeks porażenia roślin pszenicy jarej przez O. yallundae w zależności od uprawy międzyplonu w poszczególnych latach badań

Table 1. Percentage and index of spring barley plants infected by $O$. yallundae in correlation to cover crop cultivation in individual years of the research

\begin{tabular}{|c|c|c|c|c|}
\hline \multicolumn{5}{|c|}{ Procent porażenia - Percentage of infection } \\
\hline \multirow{2}{*}{ Uprawa międzyplonu - Cover crop cultivation } & \multicolumn{3}{|c|}{ lata - years } & \multirow{2}{*}{$\begin{array}{c}\text { średnio } \\
\text { mean }\end{array}$} \\
\hline & 2011 & 2012 & 2013 & \\
\hline Bez międzyplonu - Wihout cover crop & 1,33 & 1,67 & 4,33 & $2,44 \mathrm{a}$ \\
\hline Podorywka - Skimming & 2,22 & 1,67 & 1,33 & $1,74 \mathrm{a}$ \\
\hline Siew bezpośredni - Direct sowing & 1,22 & 2,00 & 5,00 & $2,74 \mathrm{a}$ \\
\hline Średnio - Mean & $1,59 \mathrm{a}$ & $1,78 \mathrm{a}$ & $3,55 \mathrm{~b}$ & - \\
\hline $\begin{array}{l}\text { NIR }(0,05) \text { dla: } \\
\operatorname{LSD}(0.05) \text { for: }\end{array}$ & \multicolumn{3}{|c|}{$\begin{array}{l}\mathrm{A} \text { - lat - years - } 1,182 \\
\mathrm{~B} \text { - międzyplonu - cover crop - r.n. } \\
\text { interakcji - interaction: } \mathrm{A} \times \mathrm{B}-2,047\end{array}$} & \\
\hline \multicolumn{5}{|c|}{ Indeks porażenia - Infection index } \\
\hline Bez międzyplonu - Wihout cover crop & 0,006 & 0,004 & 0,012 & $0,007 \mathrm{a}$ \\
\hline Podorywka - Skimming & 0,006 & 0,004 & 0,002 & $0,004 \mathrm{a}$ \\
\hline Siew bezpośredni - Direct sowing & 0,007 & 0,004 & 0,014 & $0,008 \mathrm{a}$ \\
\hline Średnio - Mean & $0,006 \mathrm{a}$ & $0,004 \mathrm{a}$ & $0,010 \mathrm{a}$ & - \\
\hline NIR $(0,05)$ dla: - LSD (0.05) for: & \multicolumn{3}{|c|}{$\begin{array}{l}\mathrm{A}-\text { lat - years }- \text { r.n. } \\
\mathrm{B} \text { - międzyplonu - cover crop - r.n. } \\
\text { interakcji - interaction: } \mathrm{A} \times \mathrm{B}-\text { r.n. }\end{array}$} & \\
\hline
\end{tabular}

r.n. - różnice nieistotne - not significant differences

Wartości oznaczone tymi samymi literami oznaczają brak istotnych różnic zgodnie z testem Tuckeya $(\mathrm{p}<0,05)$

The same small case letters among treatment means indicate not significant differences according to Tuckey's LSD test (p < 0.05)

Tabela2. Procent oraz indeks porażenia roślin pszenicy jarej przez grzyby z rodzaju Fusarium spp. w zależności od sposobu uprawy międzyplonu i gleby pod wysiew pszenicy

Table 2. Percentage and index of spring wheat plants infected by Fusarium spp. in correlation to cover crop and soil cultivation for wheat crop

\begin{tabular}{|c|c|c|c|c|}
\hline \multicolumn{5}{|c|}{ Procent porażenia - Percentage of infection } \\
\hline \multirow{2}{*}{$\begin{array}{l}\text { Sposób uprawy roli } \\
\text { Tillage system }\end{array}$} & \multicolumn{3}{|c|}{ uprawa międzyplonu - cover crop cultivation } & \multirow{2}{*}{$\begin{array}{c}\text { średnio } \\
\text { mean }\end{array}$} \\
\hline & $\begin{array}{l}\text { bez międzyplonu } \\
\text { wihout cover crop }\end{array}$ & $\begin{array}{l}\text { podorywka } \\
\text { skimming }\end{array}$ & $\begin{array}{l}\text { siew bezpośredni } \\
\text { direct sowing }\end{array}$ & \\
\hline Siew bezpośredni - Direct sowing & 21,1 & 20,1 & 22,9 & $21,4 \mathrm{a}$ \\
\hline Uproszczona - Reduced & 16,2 & 16,7 & 21,9 & $18,3 \mathrm{a}$ \\
\hline Tradycyjna-Conventional & 16,7 & 16,4 & 20,4 & $17,8 \mathrm{a}$ \\
\hline Średnio - Mean & $18,0 \mathrm{a}$ & $17,7 \mathrm{a}$ & $21,7 \mathrm{a}$ & - \\
\hline NIR $(0,05)$ dla: - LSD $(0.05)$ for: & \multicolumn{4}{|c|}{$\begin{array}{l}\mathrm{C} \text { - sposobu uprawy - tillage system - r.n. } \\
\mathrm{B}-\text { międzyplonu - cover crop }- \text { r.n. } \\
\text { interakcji - interaction: } \mathrm{B} \times \mathrm{C}-\text { r.n. }\end{array}$} \\
\hline \multicolumn{5}{|c|}{ Indeks porażenia - Infection index } \\
\hline Siew bezpośredni - Direct sowing & 0,10 & 0,10 & 0,10 & $0,10 \mathrm{a}$ \\
\hline Uproszczona - Reduced & 0,08 & 0,10 & 0,09 & $0,09 \mathrm{a}$ \\
\hline Tradycyjna-Conventional & 0,08 & 0,08 & 0,08 & $0,08 \mathrm{a}$ \\
\hline Średnio - Mean & $0,09 \mathrm{a}$ & $0,09 \mathrm{a}$ & $0,09 \mathrm{a}$ & - \\
\hline NIR $(0,05)$ dla: - LSD $(0.05)$ for & \multicolumn{4}{|c|}{$\begin{array}{l}\mathrm{C} \text { - sposobu uprawy - tillage system - r.n. } \\
\mathrm{B}-\text { międzyplonu - cover crop }- \text { r.n. } \\
\text { interakcji - interaction: } \mathrm{B} \times \mathrm{C}-\text { r.n. }\end{array}$} \\
\hline
\end{tabular}

r.n. - różnice nieistotne - not significant differences

Wartości oznaczone tymi samymi literami oznaczają brak istotnych różnic zgodnie z testem Tuckeya $(\mathrm{p}<0,05)$

The same small case letters among treatment means indicate not significant differences according to Tuckey's LSD test (p < 0.05) 
Tabela3. Procent oraz indeks porażenia roślin pszenicy jarej przez grzyby z rodzaju Fusarium spp. w zależności od sposobu uprawy gleby pod wysiew pszenicy w poszczególnych latach badań

Table 3. Percentage and index of spring wheat plants infected by Fusarium spp. in correlation to soil cultivation for wheat crop in individual years of the research

\begin{tabular}{|c|c|c|c|c|}
\hline \multicolumn{5}{|c|}{ Procent porażenia - Percentage of infection } \\
\hline \multirow{2}{*}{$\begin{array}{l}\text { Sposób uprawy roli } \\
\text { Tillage system }\end{array}$} & \multicolumn{3}{|c|}{ lata - years } & \multirow{2}{*}{$\begin{array}{c}\text { średnio } \\
\text { mean }\end{array}$} \\
\hline & 2011 & 2012 & 2013 & \\
\hline Siew bezpośredni - Direct sowing & 31,5 & 14,7 & 19,3 & $21,8 \mathrm{a}$ \\
\hline Uproszczona - Reduced & 22,5 & 15,0 & 15,7 & $17,7 \mathrm{a}$ \\
\hline Tradycyjna-Conventional & 25,7 & 14,3 & 13,7 & $17,9 \mathrm{a}$ \\
\hline Średnio - Mean & $26,6 \mathrm{a}$ & $14,7 \mathrm{~b}$ & $16,2 \mathrm{~b}$ & - \\
\hline $\operatorname{NIR}(0,05)$ dla: - $\operatorname{LSD}(0.05)$ for: & \multicolumn{3}{|c|}{$\begin{array}{l}\text { A - lat - years }-4,49 \\
\text { C - sposobu uprawy - tillage system - r.n. } \\
\text { interakcji - interaction: } \mathrm{A} \times \mathrm{C} \text { - r.n. }\end{array}$} & \\
\hline \multicolumn{5}{|c|}{ Indeks porażenia - Infection index } \\
\hline Siew bezpośredni - Direct sowing & 0,16 & 0,07 & 0,07 & $0,10 \mathrm{a}$ \\
\hline Uproszczona - Reduce & 0,13 & 0,08 & 0,06 & $0,09 \mathrm{a}$ \\
\hline Tradycyjna-Conventional & 0,13 & 0,06 & 0,03 & $0,07 \mathrm{a}$ \\
\hline Średnio - Mean & $0,14 \mathrm{a}$ & $0,07 \mathrm{~b}$ & $0,05 \mathrm{~b}$ & - \\
\hline NIR $(0,05)$ dla: - LSD $(0.05)$ for: & \multicolumn{4}{|c|}{$\begin{array}{l}\mathrm{A}-\text { lat }- \text { years }-0,03 \\
\mathrm{C}-\text { sposobu uprawy }- \text { tillage system }- \text { r.n. } \\
\text { interakcji - interaction: } \mathrm{A} \times \mathrm{C}-\text { r.n. }\end{array}$} \\
\hline
\end{tabular}

r.n. - różnice nieistotne - not significant differences

Wartości oznaczone tymi samymi literami oznaczają brak istotnych różnic zgodnie z testem Tuckeya $(\mathrm{p}<0,05)$

The same small case letters among treatment means indicate not significant differences according to Tuckey's LSD test (p < 0.05)

Tabela 4. Procent oraz indeks porażenia roślin pszenicy jarej przez G. graminis w zależności od sposobu uprawy międzyplonu i gleby pod wysiew pszenicy

Table 4. Percentage and index of spring wheat infected by G. graminis in correlation to cover crop and soil cultivation for wheat crop

\begin{tabular}{|c|c|c|c|c|}
\hline \multicolumn{5}{|c|}{ Procent porażenia - Percentage of infection } \\
\hline \multirow{2}{*}{$\begin{array}{l}\text { Sposób uprawy roli } \\
\text { Tillage system }\end{array}$} & \multicolumn{3}{|c|}{ uprawa międzyplonu - cover crop cultivation } & \multirow{2}{*}{$\begin{array}{c}\text { średnio } \\
\text { mean }\end{array}$} \\
\hline & $\begin{array}{l}\text { bez międzyplonu } \\
\text { wihout cover crop }\end{array}$ & $\begin{array}{l}\text { podorywka } \\
\text { skimming }\end{array}$ & $\begin{array}{l}\text { siew bezpośredni } \\
\text { direct sowing }\end{array}$ & \\
\hline Siew bezpośredni - Direct sowing & 27,0 & 31,4 & 17,5 & $25,3 \mathrm{a}$ \\
\hline Uproszczona - Reduced & 24,3 & 29,3 & 17,9 & $23,8 \mathrm{a}$ \\
\hline Tradycyjna-Conventional & 22,1 & 20,5 & 16,9 & $19,8 \mathrm{a}$ \\
\hline Średnio - Mean & $24,5 \mathrm{a}$ & $27,1 \mathrm{a}$ & $17,4 \mathrm{a}$ & - \\
\hline NIR $(0,05)$ dla: - LSD $(0.05)$ for: & \multicolumn{4}{|c|}{$\begin{array}{l}\mathrm{C} \text { - sposobu uprawy - tillage system - r.n. } \\
\mathrm{B} \text { - międzyplonu - cover crop - r.n. } \\
\text { interakcji - interaction: } \mathrm{B} \times \mathrm{C}-\text { r.n. }\end{array}$} \\
\hline \multicolumn{5}{|c|}{ Indeks porażenia - Infection index } \\
\hline Siew bezpośredni - Direct sowing & 6,0 & 4,3 & 3,1 & $4,5 \mathrm{a}$ \\
\hline Uproszczona - Reduced & 4,0 & 6,0 & 2,2 & $4,1 \mathrm{a}$ \\
\hline Tradycyjna-Conventional & 2,4 & 3,6 & 2,8 & $2,9 \mathrm{a}$ \\
\hline Średnio - Mean & $4,1 \mathrm{ab}$ & $4,6 \mathrm{a}$ & $2,7 \mathrm{~b}$ & - \\
\hline NIR $(0,05)$ dla: - LSD (0.05) for: & \multicolumn{4}{|c|}{$\begin{array}{l}\mathrm{C} \text { - sposobu uprawy - tillage system - r.n. } \\
\mathrm{B} \text { - międzyplonu - cover crop }-1,40 \\
\text { interakcji - interaction: } \mathrm{B} \times \mathrm{C}-2,43\end{array}$} \\
\hline
\end{tabular}

r.n. - różnice nieistotne - not significant differences

Wartości oznaczone tymi samymi literami oznaczają brak istotnych różnic zgodnie z testem Tuckeya $(\mathrm{p}<0,05)$

The same small case letters among treatment means indicate not significant differences according to Tuckey's LSD test (p < 0.05)

$(6,0)$ charakteryzowały się rośliny pochodzące z obiektów, w których nie wysiewano międzyplonu, a pszenicę upra- wiano w technologii siewu bezpośredniego, a także gdy gorczycę białą uprawiano po podrywce, a pszenicę wysie- 
wano po przygotowaniu gleby agregatem uprawowym. $\mathrm{Z}$ kolei najniższe wartości indeksu porażenia wykazano w obiektach, w których międzyplon uprawiano w siewie bezpośrednim, a pszenicę wysiewano w glebę po jej uprawie agregatem uprawowym $(2,2)$.

Literatura wskazuje, iż stosowanie uproszczonych systemów uprawy przy braku uprawy płużnej daje znikome przykrycie resztek pożniwnych (Meynard i wsp. 2003). Resztki pożniwne pozostawione na powierzchni gleby odpowiadają za wtórne porażenie następujących po sobie roślin uprawnych, gdyż stają się miejscem przetrwania dla wielu chorób, w tym również łamliwości podstawy źdźbła i fuzaryjnej zgorzeli podstawy źdźbła (Matusinsky i wsp. 2009). Baturo (2007) w swoich badaniach wskazuje na zróżnicowany skład populacji grzybów zasiedlających podstawę źdźbła. W systemie ekologicznym, w fazie początku krzewienia, izolowano liczniej Fusarium spp., jednak w fazie dojrzałości woskowej przeważającym patogenem był Bipolaris sorokiniana, a Fusarium spp. stwierdzono głównie w systemie integrowanym i konwencjonalnym. Badania te wskazują na zmieniające się w czasie wzrostu roślin zagrożenia ze strony różnych patogenów. W badaniach wykazano związek pomiędzy sposobem uprawy międzyplonu (gorczycy białej) a sposobem uprawy gleby pod wysiew pszenicy. Najwyższą wartością indeksu porażenia podstawy źdźbła charakteryzowały się rośliny pochodzące $\mathrm{z}$ obiektów, w których nie wysiewano międzyplonu, a pszenicę uprawiano w technologii siewu bezpośredniego. Uprawa międzyplonów na przyoranie jest prekursorem trwałej materii organicznej, pomaga w rozwoju mikroorganizmów glebowych oraz wpływa na fizykochemiczne właściwości gleby (Malicki i Michałowski 1994). Stały dopływ substancji organicznej do gleby w postaci międzyplonu pozwala zachować jej aktywność biologiczną, co prowadzi do poprawy stanu fitosanitarnego (Kuś i wsp. 1993).

Łamliwość źdźbła zbóż i traw należy do często występujących chorób, lecz nie tak groźnych, jak fuzaryjna zgorzel podstawy źdźbła i korzeni zbóż (Steinbrenner i Höflich 1984; Jańczak 1990). Na podstawie wieloletnich badań upraw monokulturowych stwierdzono, że łamliwość źdźbła zbóż i traw nie jest typową chorobą płodozmianową i rozwija się niezależnie od przedplonu (Kurowski 2002; Kurowski i Adamiak 2007). O występowaniu tej choroby decydują przede wszystkim warunki klimatyczne (Pecio i Danyte 2008). Z danych literaturowych wynika, iż silnemu rozwojowi łamliwości podstawy źdźbła sprzyjają temperatura od 4 do $10^{\circ} \mathrm{C}$, względna wilgotność powietrza powyżej 80\% i codzienne opady powyżej $3 \mathrm{~mm}$ (Korbas 2004; Matusinsky i wsp. 2009). Badania własne potwierdziły związek między przebiegiem warunków pogodowych a występowaniem tej choroby. Największe porażenie łamliwością źdźbła zbóż i traw obserwowano w wilgotnym 2013 roku.

\section{Wnioski / Conclusions}

1. Siew bezpośredni przyczynił się do większego porażenia pszenicy jarej przez choroby podstawy źdźbła i korzeni. W obiektach, w których nie pozostawiano biomasy z gorczycy białej, w każdym roku badań obserwowano wyższe porażenie zarówno fuzaryjną zgorzelą podstawy źdźbła, jak i zgorzelą podstawy źdźbła.

2. Procent uszkodzeń roślin, jak i wartość indeksu porażenia przez grzyby powodujące zgorzel podstawy źdźbła uzależnione były od badanych czynników doświadczalnych. Wyższe porażenie obserwowano w obiektach bez uprawy międzyplonu, w których pszenicę uprawiano w technologii bezorkowej.

Praca naukowa finansowana ze środków Narodowego Centrum Nauki w ramach projektu badawczego N N 310 027339.

\section{Literatura / References}

Baturo A. 2007. Effect of organic system on spring barley stem base health in comparison with integrated and conventional farming. J. Plant Prot. Res. 47 (2): 167-178.

Czaban J., Wróblewska B., Sułek A., Podolska G. 2011. Wpływ różnych technologii produkcji pszenicy ozimej na zasiedlanie jej ziarna przez grzyby z rodzaju Fusarium. Pol. J. Agron. 5: 11-20.

Duer I. 1996. Mulczujący wpływ międzyplonu na plonowanie jęczmienia jarego oraz zawartość wody i azotanów w glebie. Fragm. Agron. 1 (49): 29-43.

EPPO Standards 1998. Guidelines on Good Plant Protection Practice. PP 1/28 (3).

Huber D.M., McCay-Bius T.S. 1993. A multiple component analysis of the take-all disease of cereals. Plant Dis. 77: $437-447$.

Jańczak C. 1990. Zwalczanie chorób pszenicy ozimej opryskiwaniem fungicydami w okresie wegetacji. Prace Nauk. Inst. Ochr. Roślin $32(1 / 2): 15-52$.

Korbas M. 2004. Choroby podstawy źdźbła, możliwości i perspektywy zwalczania. [Culm base diseases - possibilities and perspective of their control]. Prog. Plant Prot./Post. Ochr. Roślin 44 (1): 147-154.

Krupinsky J.M., Tanaka D.L., Merrill S.D., Liebig M.A., Lares M.T., Hanson J.D. 2007. Crop sequence effects on leaf spot diseases of no-till spring wheat. Agron. J. 99: 912-920.

Kurowski T. 2002. Studia nad chorobami podsuszkowymi zbóż uprawianych w wieloletnich monokulturach. Wyd. UWM Olszt. Rozpr. Nauk. 56, 86 ss.

Kurowski T.P., Adamiak E. 2007. Occurrence of stem base diseases of four cereal species grown in long-term monocultures. Pol. J. Natural Sci. 22 (4): 574-583.

Kuś J., Siuta A., Mróz A., Kamińska M. 1993. Możliwość kompensacji ujemnego wpływu stanowiska na plonowanie jęczmienia jarego. Pam. Puł. 103: 133-143. 
Malicki L., Michałowski C. 1994. Problem międzyplonów w świetle doświadczeń. Post. Nauk Rol. 4: 4-18.

Matusinsky P., Mikolasova R., Klem K., Spitzer T. 2009. Eyespot infection risks on wheat with respect to climatic conditions and soil management. J. Plant Pathol. 91 (1): 93-101.

Meynard J.M., Doré T., Lucas P. 2003. Agronomic approach: cropping systems and plant diseases. Comptes Rendus Biologies 326: 37-46.

Pecio A., Danyte V. 2008. Wpływ warunków pogody na porażenie zbóż jarych patogenami liści i kłosów. [The influence of weather conditions on infections of spring cereals with leaf and ear pathogens]. Prog. Plant Prot./Post. Ochr. Roślin 48 (2): $499-503$.

Pląskowska E., Matkowski K., Moszczyńska E., Kordas L. 2002. Zdrowotność podstawy źdźbła pszenicy jarej w uprawie tradycyjnej i siewie bezpośrednim przy dwóch poziomach nawożenia azotem. Acta Sci. Pol., Agricultura 1 (1): 131-138.

Richards I., Wallace P., Turner I. 1996. A comparison of six cover crop types in terms of nitrogen uptake and effect on response to nitrogen by a subsequent spring barley crop. J. Agric. Sci. Camb. 127: 441-449.

Steinbrenner K., Höflich G. 1984. Einfluss acker- und pflanzenbaulicher Maßnahmen auf den Befall des Getreides durch Pseudocercosporella herpotrichoides (Fron) Deighton und Gaeumannomyces graminis (Sacc.) Arx et Olivier. Arch. Phytopathol. Pflanzenschutz 20 (6): 469-486.

Weber R., Hryńczuk B., Runowska-Hryńczuk B., Kita W. 2001. Influence of the mode of tillage on diseases of culm base in some winter wheat varieties, oats and spring wheat. J. Phytopathol. 149: 185-188.

Wojciechowski W. 2005. Oddziaływanie przyorywanych międzyplonów ścierniskowych i nawożenia azotem na zdrowotność roślin pszenicy jakościowej. [The effect of ploughing down stubble crops and nitrogen fertilization on health status of quality wheat]. Prog. Plant Prot./Post. Ochr. Roślin 45 (2): 1197-1199. 